\title{
Urban Ecological and Social-Ecological Research in the City of Cape Town: Insights Emerging from an Urban Ecology CityLab
}

\author{
Pippin Anderson ${ }^{1}$ and Thomas Elmqvist ${ }^{2}$
}

Key Words: African Centre for Cities; Cape Town; CityLab; social urban ecology; urban ecology

\section{INTRODUCTION}

There is an ecology that is particular to the urban (Breuste et al. 2008). Urban ecological systems are deeply situated in the functioning of society, and as such have unique drivers and selection pressures (Collins et al. 2000, Yli-Pelkonen and Niemela 2005, Sochat et al. 2006). What has emerged in recent work is a complex of in- and of- city ecologies which strive to address sustainability at multiple scales, often in the context of joint anthropogenic and conservation agendas (Grimm et al. 2008). In the City of Cape Town there are multiple demands on urban land use to meet development and conservation needs. The consequences of an unjust history are still very much evident in the City of Cape Town today where development discrepancies are acute and the demand for short term delivery high (Turok and Watson 2001). The City is also host to exceptional, and geographically restricted, biodiversity, on a scale that gives it international conservation attention (Myers et al. 2000). Like other cities around the world, Cape Town has seen phenomenal population growth in the last century, growing from just over 630,000 in 1951, to 3.7 million today (Quick 1995, City of Cape Town 2010). This developing City, situated in the south, with its myriad of social and environmental issues, playing out at various scales, makes Cape Town both a relevant and exciting place to further the field of urban ecology.

\section{A SHORT OVERVIEW OF THE EMERGENCE OF THE 'DISCIPLINE'}

Ecologists have doggedly avoided research in the urban (Grimm et al. 2008, Cadenasso and Pickett 2008), but recently there has been growing recognition of the importance of people as both ecosystem drivers and, increasingly, as integral parts of ecological systems (Marzluff et al. 2008). Combined with the global trend of rapid urbanization, the unique ecology in and of the city is seen as central to broader sustainability (Anderssen 2006). In light of this urban ecology is now recognized as an important science in itself (Niemela et al. 2011).

While the term 'urban ecology' was used in sociology and planning schools with variable meaning though the last century, urban ecology as a subdiscipline of ecology only emerged in the 1970s in response to a growing awareness of human impact on the natural environment, and the role of cities in this regard (MacDonnell 2011, Cadenasso and Pickett 2008). This legacy has seen both the scientific and planning realms bought together in urban ecology (Pickett et al. 2008), which continues to strive to integrate both fundamental and applied research (MacDonnell 2011). Essentially cities make for heterogeneous landscapes of high temporal and spatial diversity, and urban ecology explores the links and relationships (be they positive or negative) between the ecosystems and species that make up this complex matrix and the associated human activities (Pickett et al. 2008). We now understand that it is both cultural and biological diversity that underpin resilience and sustainability (Anderssen 2006). Urban ecological research has materialized in two forms recognized now as ecology in and ecology of the city (Pickett et al. 2001, MacDonnell 2011). Ecology in the city speaks to those studies that are local in scale while ecology of the city speaks to research that is multi-scalar, and inter-disciplinary (Grimm et al. 2008, Pickett et al. 2001). While there is a fair amount of research on the ecology in the urban, the ecology of the urban is somewhat further behind (MacDonnell 2011). There is a particular need to understand how urban regions may contribute to better stewardship of distant landscapes which generate many of the ecosystem services consumed (Folke et al. 1997). In ecology there is now a growing understanding that human processes and cultures are fundamental for sustainable management of ecosystems, and in urban planning it is becoming more and more evident that urban management needs to operate at an ecosystem scale that is beyond the traditional boundaries of the city, both with respect to the biophysical and social (Elmqvist et al. 2008, Rees 1997). Mismatches between spatial and temporal scales of ecological process on the one hand, and social scales of monitoring and decision making on the other have in the past not only limited our understanding of ecological processes in urban landscapes, but have also limited the integration of urban ecological knowledge into urban planning.

Although the challenges facing urban areas are many and complex, Evans (2011) suggests that it is in the very diversity and density of population presented in cities that the solutions to our problems lie. The city can serve as laboratory: a space fertile with cultural, social, spatial, temporal, institutional and

\footnotetext{
${ }^{1}$ African Centre for Cities, Environmental and Geographical Science Department, University of Cape Town, South Africa, ${ }^{2}$ Stockholm Resilience Center, Stockholm University, Sweden
} 
biological diversity from which can emerge novel ideas to be tried and tested. It is here among the bulk of the population, at the point of greatest consumption, that we should be engaging with questions of ecological functionality and environmental sustainability (Grimm et al. 2008). In line with the notion of the city as laboratory, in 2009 the African Centre for Cities (ACC), at the University of Cape Town, launched the CityLab programme. The idea was to create a space in which responsive knowledge could be generated and shared through partnership between the academy, civil society, and those governing the city. Parnell et al. (2009) note with urgency the need to produce south-derived knowledge to inform theoretical reform and that this should be generated in a manner that makes it both easily accessible and of ready practical benefit to local decision makers, and the CityLabs strive to do just this. This is particularly pertinent to urban ecology, which has epistemological origins predating its uptake by the ecological fraternity in the realm of city planning (MacDonnell 2011). In 2010 the Urban Ecology CityLab was initiated, as one of a number of thematic CityLabs. This CityLab ran a year-long seminar series which served to bring together researchers and practitioners from different disciplinary and professional areas to share knowledge, pose questions, and carry out empirical work around the ecology of the City of Cape Town. An important output from the initial stage of each CityLab is some form of publication to serve both as a record of the CityLab engagement, and in response to Parnell et al.'s (2009) call for the dissemination of new knowledge as part of the process of theoretical reform. This Special Feature is the outcome of the ACC Urban Ecology CityLab process.

The Urban Ecology CityLab, and this emerging Special Feature, has brought to light a number of important findings in relation to urban ecological and social-ecological research in the City of Cape Town. What is immediately apparent is that there is a substantial understanding of ecology in the City, with some growing movement in the area of the ecology of the City. Urban ecological research in Cape Town is largely, but not entirely, taking place in isolation. This mirrors for example the various tiers of governance of green space in the City where the National Government runs the Table Mountain National Park, and the City of Cape Town is responsible for the lowland conservation areas resulting in obvious disjuncts. The same might be said for disciplinary isolation, but this is perhaps less prevalent where simply by working in the City different disciplines must engage, and we see for example zoologists linking up with those working in the realm of spatial planning. Where collaborations are strongest they appear to emerge in response to issue-driven engagements, and are generally happening between practitioners in the City of Cape Town who actively seek research input from Government research entities such as South Africa's Council for Scientific and Industrial Research (CSIR) or the South African National
Biodiversity Institute (SANBI). Cilliers and Siebert (2012) remind us that true transdisciplinary engagement both between disciplines and across sectors is necessary to forward an urban ecology research agenda and see it embedded into planning processes.

Substantive, empirical, findings have emerged. We see strong evidence of the significance of the spatial with respect to ecological and social processes where distances to resources, connectivity and boundaries are all important drivers of social engagement and ecological function (O'Farrell et al. 2012, Hoffman and O'Riain 2012, Pauw and Louw 2012). Natural resource management and conservation in the City are generally well supported by good policy and planning instruments, but the knowing-doing gap is a persistent problem (Holmes et al. 2012). Opportunities exist for the effective comanagement or resources with better engagement with greater society, but these arrangements while potentially effective, require ongoing and critical review (Graham and Ernstson 2012). There is specificity around species response, or at least functional type, in the urban that point to a need for considerable additional research echoing similar calls in the international literature (O'Farrell et al. 2012, Pauw and Louw 2012, Hoffman and O'Riain 2012). We know that ecosystem services in the City generate significant income every year (Petersen et al. 2012, de Wit et al. 2009), and knowledge of where these ecosystem services 'play out' in the landscape, and who might benefit from them is now apparent and can better inform spatial planning and management (O'Farrell et al. 2012). The natural environment forms a significant part of informal (Petersen et al. 2012) economy which warrants far greater attention. Societal expectations and perceptions inform ecological process, for example in the management of invasive alien plant species and fire, and managing these attitudes is one of the greatest challenges to promoting a functional ecology in the city (van Wilgen 2012, van Wilgen et al. 2012). An examination of change through time brings new insights to bear on society's engagement with its environment and the process of making a benign urban environment, in keeping with recent frameworks for understanding urban ecologies (Anderson and O'Farrell 2012, O'Farrell et al. 2012, Ramalho and Hobbs 2012). Evident throughout this Special Feature is the fact that the City of Cape Town has a remarkable natural environment, and that this is interwoven in the everyday lives of the people of the City and plays out at multiple scales. In many respects this is a complex love-hate relationship, but one that must persist for the resilience of the City in the face of future global change (Cartwright et al. 2012). Cilliers and Siebert (2012) reflect on the empirical findings in the broader context of urban ecological research in South Africa, clearly demonstrating the contribution this Special Feature makes to a growing body of work. They note too where research in Cape Town may be missing opportunities and in particular note the dominating force of the Cape's high biodiversity in driving a 
particular research agenda. Potential for comparative work are currently relatively few, but opportunities to look at other cities and learn, in particular with respect to the use of urban ecological information to inform city management in Durban, are plentiful.

Urban ecological and social-ecological research in Cape Town, like in other areas of the world, has largely been done by isolated research entities. We have a strong understanding of many aspects of the functioning ecology of the City, but need to start taking a more holistic and integrated approach to our empirical work in the future, in keeping with global trends. The work presented in this Special Feature should serve as a basis to forward urban ecology work in Cape Town, both with respect to growing the empirical understanding of the ecology in the City, which this issue has shown to be nuanced and relevant, and also towards the less explored ecology of the City as a whole. New conceptual areas worthy of exploration are numerous, but some of the outstanding City-scale questions would relate to types of management of urban ecosystems that may protect biodiversity, generate multiple ecosystem services and at the same time contribute to both mitigation and adaption to climate change and, in contrast, analyze under which conditions and types of management where such synergies are difficult or impossible. Numerous opportunities for new collaborative and comparative work are evident (Cilliers and Siebert 2012) and the way ahead for urban ecological research in South Africa is wide open.

The CityLab project and coproduction process has served to bring together, into one dedicated space, a substantial amount of work and empirical understanding of facets of the ecology of the City of Cape Town. It has also served to demonstrate patterns of research and practice engagement, and highlight gaps and opportunities. The initial phase of the CityLab project has been productive, but also points to future research opportunities. There is an evident opportunity to generate a new research agenda in a way that would allow for a much more significant cross-discipline and practice engagement. While the geographic focus of this Special Feature is specific, these final points are universal. The urban landscape provides a public space for the cross-fertilization of minds and various disciplines, enabling new perspectives that place human wellbeing at the core, break the artificial divide between the pristine and the human-dominated ecosystems, and contribute to the creation of new concepts, tools and institutions that would gather rather than divide, and establish responsible environmental stewardship at the heart of public interest (Niemela et al. 2011).

Responses to this article can be read online at: http://www.ecologyandsociety.org/issues/responses. php/5076

\section{Acknowledgments:}

This paper is a product of the Urban Ecology CityLab which is part of the CityLab programme of the African Centre for Cities at the University of Cape Town. The African Centre for Cities' CityLab programme is funded through the Mistra Urban Futures network (which is funded by Mistra the Foundation for Strategic Environmental Research and the Swedish International Development Cooperation Agency), the Provincial Government of the Western Cape (Department of Human Settlements) and the City of Cape Town.

\section{LITERATURE CITED}

Anderson, P. M. L., and P. J. O'Farrell. 2012. An ecological view of the history of the City of Cape Town. Ecology and Society 17(3): 28. http://dx.doi.org/10.5751/ES-04970-170328

Anderssen, E. 2006. Urban landscape and sustainable cities. Ecology and Society 11(1): 34. [online] URL: http://www. ecologyandsociety.org/vol11/iss1/art34

Breuste, J., J. Niemela,. and R. P. H. Snep, 2008. Applying landscape ecological principles in urban environments. Landscape Ecology 23: 1139-1142. http://dx.doi.org/10.1007/ s10980-008-9273-0

Cadenasso, M. L., and S. Pickett. 2008. Urban principles for ecological landscape design and management: scientific fundamentals. Cities and the Environment 1(2):1-16.

Cartwright, A., G. Oelofse, S. Parnell, and S. Ward. 2012. Climate at the city scale. in A. Cartwright, S. Parnell, G. Oelofse, and S. Ward. (Editors) Climate Change at the City Scale: Impacts, Mitigation and Adaptation in Cape Town. Routledge, London. UK.

Cilliers, S. S. and S. J. Siebert. 2012. Urban ecology in Cape Town: South African comparisons and reflections. Ecology and Society 17(3): 33. http://dx.doi.org/10.5751/ES-05146-170333

City of Cape Town. 2010. Urbanisation and poverty in Cape Town, working document. City of Cape Town, South Africa.

Collins J. P., A. Kinzig, N. B. Grimm. 2000. A new urban ecology. American Scientist 88: 416-425. http://dx.doi. org/10.1511/2000.5.416

De Wit, M. P., H. Van Zyl, D. J. Crookes, J. N. Blignaut, T. Jayiya, V. Goiset, and B. K. Mahumani. 2009. Investing in Natural Assets. A Business Case for the Environment in the City of Cape Town. Report prepared for the City of Cape Town, Cape Town, South Africa, 18 August.

Elmqvist T., C. Alfsen, and J. Colding. 2008. Urban systems. in S. E. Jørgensen, and B. D. Fath (Editors) Ecosystems. Vol. [5] of Encyclopedia of Ecology, 5 vols. pp. 3665-3672. 
Elsevier, Oxford, UK. http://dx.doi.org/10.1016/ B978-008045405-4.00364-5

Evans, J. P. 2011. Resilience, ecology and adaptation in the experimental city. Transactions of the Institute of British Geographers 36 (2): 223 - 237. http://dx.doi.org/10.1111/ j.1475-5661.2010.00420.x

Folke, C., A. Jansson, J. Larsson, and R. Costanza. 1997. Ecosystem appropriation by cities. Ambio 26(3): 167-172.

Graham, M., and H. Ernstson. 2012. Comanagement at the fringes: examining stakeholder perspectives at Macassar Dunes, Cape Town, South Africa - at the intersection of high biodiversity, urban poverty, and inequality. Ecology and Society 17(3): 34. http://dx.doi.org/10.5751/ES-04887-170334

Grimm, N. B., S. H. Faeth, N. E. Golubiewski, C. L. Redman, J. Wu, Z. Bai, and J. M. Briggs. 2008. Global change and the ecology of cities. Science 319: 756-760. http://dx.doi. org/10.1126/science.1150195

Hoffman, T. S. and M. Justin O'Riain. 2012. Monkey management: using spatial ecology to understand the extent and severity of human-baboon conflict in the Cape Peninsula, South Africa. Ecology and Society 17(3): 13. http://dx.doi. org/10.5751/ES-04882-170313

Holmes, P. M., A. G. Rebelo, C. Dorse, and J. Wood. 2012. Can Cape Town's unique biodiversity be saved? Balancing conservation imperatives and development needs. Ecology and Society 17(2): 28. http://dx.doi.org/10.5751/ES-04552-170228

MacDonnell, M. J., 2011. The history of urban ecology - an ecologist's perspective. in J. Niemela, J. Breuste, T. Elmqvist, G. Guntenspergen, P. James and N. MacIntyre (Editors) Urban Ecology: Patterns, Processes and Applications. Oxford Biology, Oxford, UK.

Marzluff, J. M., E. Shulenberger, W. Endlicher, M. Alberti, G. Bradley, C. Ryan, U. Simon, and C. ZumBrunnen (Editors). 2008. Urban ecology - an international perspective on the interaction between humans and nature. Springer, New York.

Myers, N., R. A. Mittermeyer, G. A. Fonseca, and J. Kent. 2000. Biodiversity hotspots for conservation priorities. Nature 403: 853-858. http://dx.doi.org/10.1038/35002501

Niemela, J., J. Breuste, T. Elmqvist, G. Guntenspergen, P. James, and N. MacIntyre. 2011. Introduction. in J. Niemela, J. Breuste, T. Elmqvist, G. Guntenspergen, P. James and N. MacIntyre (Editors) Urban Ecology: Patterns, Processes and Applications. Oxford Biology, Oxford, UK.

O'Farrell, P. J., P. M. L. Anderson, D. C. Le Maitre, and P. M. Holmes. 2012. Insights and opportunities offered by a rapid ecosystem service assessment in promoting a conservation agenda in an urban biodiversity hotspot. Ecology and Society 17(3): 27. http://dx.doi.org/10.5751/ES-04886-170327

Pauw, A., and K. Louw. 2012. Urbanization drives a reduction in functional diversity in a guild of nectar-feeding birds. Ecology and Society 17(2): 27. http://dx.doi.org/10.5751/ ES-04758-170227

Parnell, S., E. Pieterse, and V. Watson. 2009. Planning for cities in the Global South: an African research agenda for sustainable human settlements. Progress in Planning 72: 233241.

Petersen, L. M., E. J. Moll, R. Collins, and M. T. Hockings. 2012. Development of a compendium of local, wild-harvested species used in the informal economy trade, Cape Town, South Africa. Ecology and Society 17(2): 26. http://dx.doi. org/10.5751/ES-04537-170226

Pickett, S. T. A., M. L.Cadenasso, J. M. Grove, C. H. Nilon, R. V. Pouyat, W. C. Zipperer, and R. Costanza. 2001. Urban ecological systems: linking terrestrial ecological, physical, and socioeconomic components of metropolitan areas. Annual Review of Ecological Systematics 32: 127-157. http://dx.doi. org/10.1007/978-0-387-73412-5 7

Pickett, S. T. A., M. L.Cadenasso, J. M. Grove, P. M. Groffman, L. E. Band, C. G. Boone, W. R. Burch, C. S. B. Grimmond, J. Hom, J. C. Jenkins, N. L. Law, C. H. Nilon, R. V. Poyat, K. Szlavevecz, P. S. Warren, and M. A. Wilson. 2008. Beyond urban ledgends: an emerging framework of urban ecology, as illustrated by the Baltimore ecosystem study. BioScience 58: 139-150. http://dx.doi.org/10.1641/ B580208

Quick, A.J.R. 1995. Issues facing water resource managers and scientists in a rapidly growing coastal city: Cape Town, South Africa. South African Journal of Science 91: 175-183.

Ramalho, C. E. and Hobbs, R. J. 2012. Time for change: dynamic urban ecology. Trends in Ecology and Evolution 27 (3): 180-188. http://dx.doi.org/10.1016/j.tree.2011.10.008

Rees, W. 1997. Urban ecosystems: the human dimension. Urban Ecosystems 1: 63 - 75. http://dx.doi.org/10.1023/ A:1014380105620

Sochat, E., P. S. Warren, S. H. Faeth, and N. McIntyre. 2006. From patterns to emerging processes in meachnistic urban ecology. Trends in Ecology and Evolution 21: 186-191. http:// dx.doi.org/10.1016/j.tree.2005.11.019

Turok, I. and V. Watson. 2001. Divergent development in South African Cities. Urban Forum 12 (2): 119 - 138. http:// dx.doi.org/10.1007/s12132-001-0013-7

Van Wilgen, B. W. 2012. Evidence, perceptions, and tradeoffs associated with invasive alien plant control in the Table 
Mountain National Park, South Africa. Ecology and Society 17(2): 23. http://dx.doi.org/10.5751/ES-04590-170223

van Wilgen, B. W., G. G. Forsyth, and P. Prins. 2012. The management of fire-adapted ecosystems in an urban setting: the case of Table Mountain National Park, South Africa. Ecology and Society 17(1): 8. http://dx.doi.org/10.5751/ ES-04526-170108

Yli-Pelkonen, V. and J. Niemela. 2005. Linking ecological and social systems in cities: urban planning in Finland as a case. Biodiversity and Conservation 14: 1947-1967. http://dx. doi.org/10.1007/s10531-004-2124-7 